\title{
FUNCTIONAL REGIONS: CONCEPT AND TYPES
}

\section{FUNKČNÍ REGIONY: KONCEPT A TYPY}

\author{
Mgr. Pavel KLAPKA, Ph.D. ${ }^{1}$ \\ DOC. RNDr. MARIÁN HALÁS, PH.D. ${ }^{1}$ \\ Mgr. Petr TONEV ${ }^{2}$ \\ ${ }^{1}$ Katedra geografie ${ }^{1}$ Department of Geography \\ Př́rodovédecká fakulta Faculty of Science \\ Univerzita Palackého v Olomouci Palacký University in Olomouc \\ $\triangle$ 17. listopadu 12, 77146 Olomouc, Czech Republic \\ E-mail:pavel.klapka@upol.cz,marian.halas@upol.cz \\ ${ }^{2}$ Katedra regionální ekonomie a správy $\mid{ }^{2}$ Dep. of Regional Economics and Administration \\ Ekonomicko-správni fakulta Faculty of Economics and Administration \\ Masarykova univerzita Masaryk University \\ $\triangle$ Lipová 4la, 60200 Brno, Czech Republic \\ E-mail:tonev@econ.muni.cz
}

\begin{abstract}
Annotation
The contribution is concerned with a concept of a region in spatial and regional science. A number of terms related to specific instances of a region can cause a misinterpretation of the concept both in scientific and applied sphere. The objective of the contribution is to provide a concise theoretical introduction into a concept of a region, particularly of a region based on functional horizontal spatial relations, and a typology of functional regions. The discussion of different types of regions and their semantic content is put forward as well. Based on the relevant literature and own research six types of regions have been identified and their position in the spatial and regional science shortly explained.
\end{abstract}

Key words

functional region, nodal region, functional urban region, daily urban system, local labour market area

\section{Anotace}

Př́spěvek se zabývá konceptem region v regionální a prostorové vědě. řada termínů spojených se specifickými prípady regionů může způsobit špatné pochopení tohoto konceptu jak v odborné tak aplikované sfére. Cílem př́spěvku je poskytnout stručný teoretický úvod ke konceptu regionu, především regionu založenému na funkčnich horizontálních prostorových vztazích, a $k$ typologii funkčnich regionů. Předkládáme rovněž diskusi různých typů regionů a jejich významového obsahu. $\mathrm{Na}$ základě relevantni literatury a vlastního výzkumu identifikujeme šest typů regionů a krátce objasňujeme jejich postavení v prostorové a regionální vědě.

\section{Klíčová slova}

funkční region, nodální region, funkční městský region, denni urbánni systém, lokálni trh práce

JEL classification: J01, J40, R10, R12 


\section{Introduction}

The objective of the contribution is to make some notes on the character and structure of functional regions and to outline a typology of these regions, since the terminology is often used interchangeably and can lead into misleading conclusions and conception of regions based on spatial relations. In our argumentation we are going to limit ourselves to the discussion of the term "region" as conceived within social sciences. Generally, the conception of region reflects the fact that the planet Earth is a conspicuously heterogeneous object and that it shows distinct differences in its spatial (i.e. geographical) characteristics.

The region is one of the basic and original concepts in geography and related spatial disciplines such as regional economics (e.g. Haggett 1965). The existence of regions is considered to be an objective reality (Bašovský, Lauko 1990), since we are able to identify their boundaries across the geographical sphere. A region is a limited spatial system and an expression of an organisational unity that differ it from another region (Abler, Adams, Gould 1972; Morrill 1974; Johnston et al. 2000; Klapka, Tonev 2008; Gregory et al. 2009). As such a region is a product of spatial or areal differentiation of geographical sphere. Its role in human geographical, regional geographical and spatial research and application is threefold (Dziewoński 1967). It can act as 1) a tool of geographical research, 2) an object of geographical research, and 3) a tool of spatial management and planning. In the first case a region is a statistical unit serving a particular research objective, in the second case it is a goal to be achieved by the research, and finally in the third case it is conceived as an area or specific territory for which a certain spatial, development, regulatory etc. plan is made.

\section{Concept of the functional region}

Geography and spatial science usually recognise two types of regions according to their form: formal and functional (see e.g. Haggett 1965; Abler, Adams, Gould 1972; Bašovský, Lauko 1990; Claval 1998; Klapka, Tonev 2008), our interest being the latter in this contribution. The term "functional region" has been introduced into human geography by Philbrick (1957), Nystuen, Dacey (1961), Haggett (1965) and Dziewoński (1967).

While the formal region is organised (or "tied together") vertically, the concept of site being of interest (Ullman 1980), the functional region is generally organised by horizontal relations in space (fig. 1) in a form of spatial flows or interactions of various kind (persons, goods, material, energy, information etc.) between parts of a region, the concept of situation being of interest (Ullman 1980). These flows and interactions have a character of a vector, i.e. they are oriented. This type of a organisational unity of a functional region infers that it usually has a heterogeneous inner structure in comparison to formal (or homogeneous) regions and that this inherent heterogeneity has to be defined in terms of quantitative or qualitative expression in order to hold a region together and to differ it from other regions. 
Fig. 1: Organisation of formal and functional region (site vs. situation)

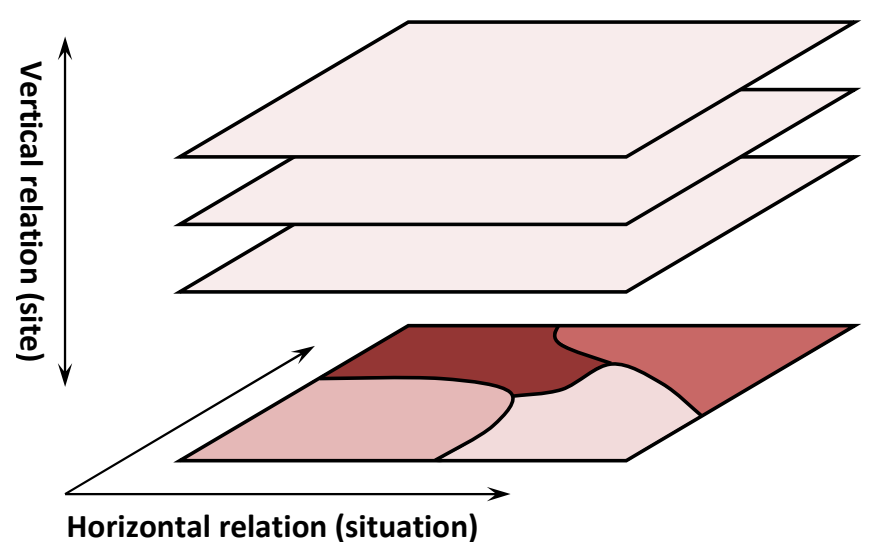

Source: own design

However, the inner structure of a generally conceived functional region is not easy to be defined as in specific types of functional regions (see further). At this place we can conclude that the inner structure reflects different intensities of spatial relations organising a functional region and that a functional region, unlike a common opinion, does not have to have a core.

As such a general functional region is understood as a region organised by functional relations that are maximised within the region (maximisation of intra-regional flows or interactions) and minimised across its borders (minimisation of inter-regional flows or interactions) so that the principles of internal cohesiveness and external separation regarding the intensities of spatial flows or interactions are met (fig. 2). It means that a functional region is an autonomous section of space in terms of horizontal spatial relations. Quantitatively these principles are expressed by the so called "selfcontainment" of a region, which generally says that the higher is the self-containment the better a region differs from other regions.

The self-containment of a region can be defined in a simple way (see fig. 2): $A+B>C+D$ which means that a region reaches at least $50 \%$ self-containment and fulfils the minimum definition of a functional region. If the level of self-containment needs to be increased a constant $k$ is defined and the condition can be written as $A+B>k(C+D) ; k>1$.

\section{Fig. 2: Principles of internal cohesiveness and external separation (self-containment of a region)}

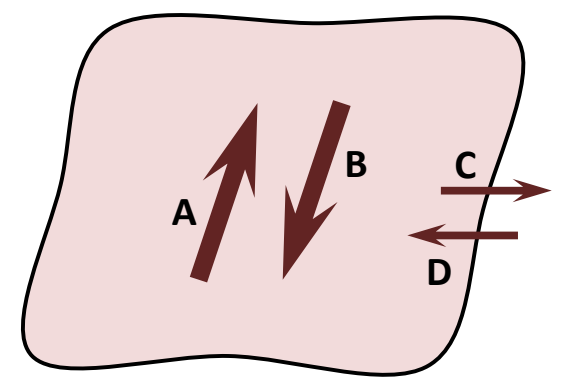

Source: own design

\section{Types of functional regions}

We propose an initial classification of functional regions conceived as autonomous units, which is based on the inner patterns of region-organising interactions or flows (fig. 3 and fig. 4) as a classification criterion. Thus in a first level functional regions with random and ordered inner pattern of interactions are identified. The second level of classification differentiates within functional regions 
with ordered structure of interactions types based on the character of ordering of region-organising interactions or flows.

Four types of regions are identified (fig. 3 and fig. 4), all of them fulfilling the principles of internal cohesiveness and external separation that make them autonomous units, some of being rather theoretical:

- functional region with oriented ordered interactions, which is characterised by a prevailing direction of flows,

- functional region with channelled ordered interactions, which is characterised by a concentration of flows into communication channels,

- functional region with circular ordered interactions, which is characterised by closed circling flows, and

- functional region with nodal ordered interactions, which is characterised by a directions of flows towards a node.

Fig. 3: Initial classification of functional regions

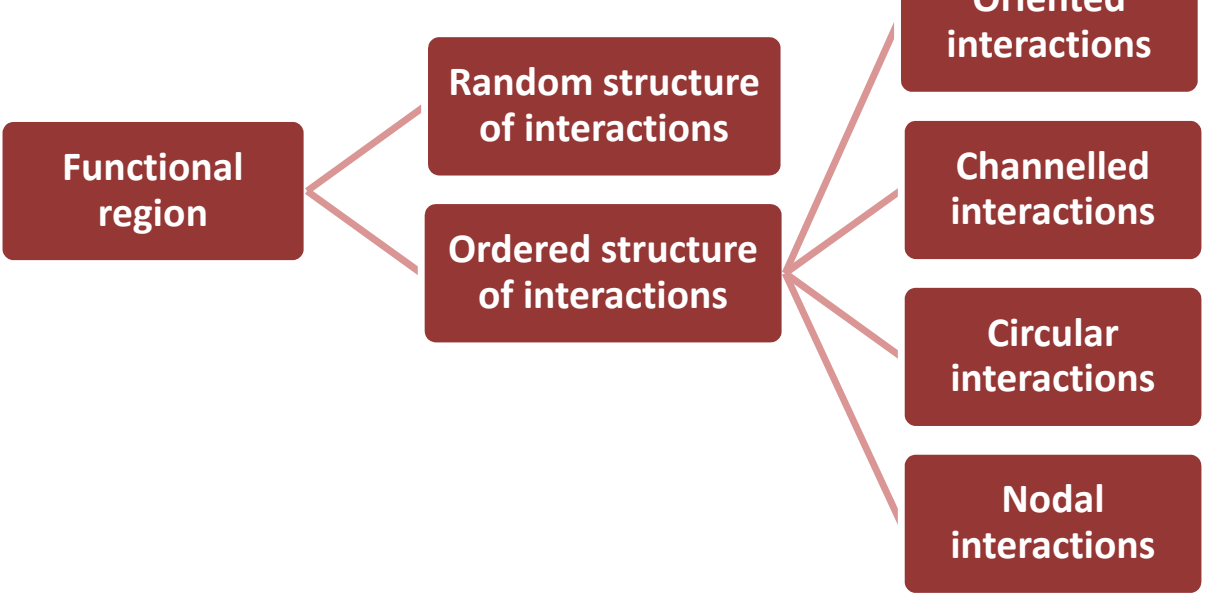

Source: own design

Fig. 4: Examples of functional regions

a) Random

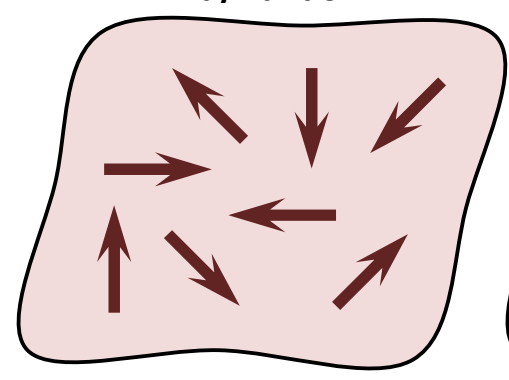

d) Circular b) Oriented

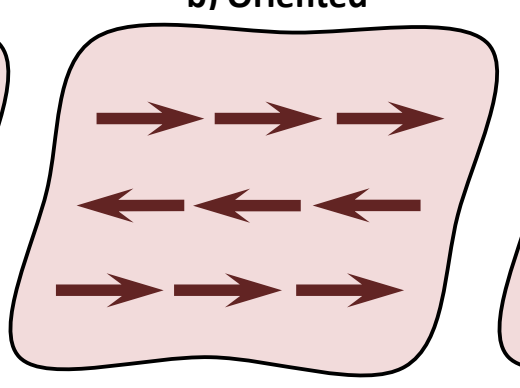

c) Channelled

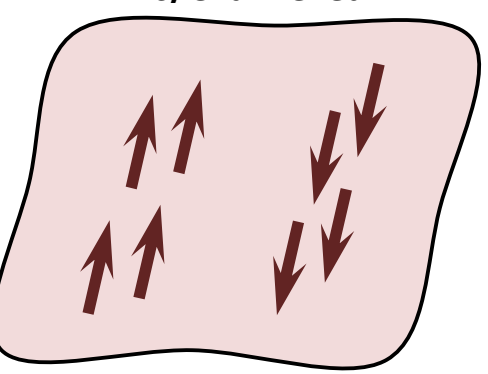

e) Nodal

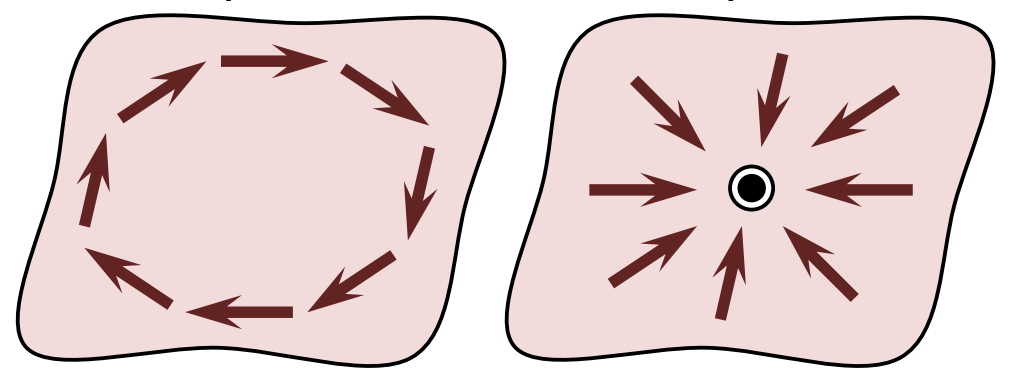

Source: own design 
In further discussion we aim at a certain refinement of the previous initial classification and we identify specific instances of functional regions, whose characteristics are not based on the inner pattern of interactions only. First we differentiate between a general functional region and a nodal region as they have been discussed for instance by Nystuen, Dacey 1961 or Brown, Holmes 1971 and as they are usually understood (e.g. Haggett 1965, Dziewoński 1967, Bašovský, Lauko 1990, Claval 1998).

Functional region matches fully the concept of the functional region with random inner pattern of interactions as defined above (fig. 4a). Thus it is a general type which is only limited by the principles of internal cohesiveness and external separation, or a principle of autonomy in other words. Any kind of spatial flow or interaction can organise this region. Its inner structure is random and varied. The functional region can even be unsuspectedly homogeneous internally.

Nodal region conforms in most cases to the concept of the functional region with nodal ordered interactions (fig. 4e), which adds the limitation coming out from its internal structure, in other respects it shows the same traits as the functional region. The novelty lies in the particular orientation of spatial flows or interactions that are centred to or radiate from the so called node (also nucleus, focus, usually centre or core). As such the nodal region is organised around its core and its inner structure is developed better than in the case of the functional region. Nodal region however demonstrates one important difference from the functional region with nodal ordered interactions and that is the nodal region does not necessarily have to comply with internal cohesiveness and external separation principles, since the primary characteristic of its identification is a nodal nature of interactions or flows, not the level of their containment within a region.

The nodal region has typically a core, a hinterland, and a periphery (fig. 5). Its internal structure and identification of its parts is based on the intensities of spatial flows or interactions between a core and its hinterland and periphery. These interaction intensities decrease with a distance from a core, the hinterland being related to the core by stronger ties than the periphery of the nodal region. This interaction decrease is not linear and its research is one of the crucial issues in quantitative geography (in Czech environment see for instance Halás, Klapka 2012).

\section{Fig. 5: Inner structure of nodal region}

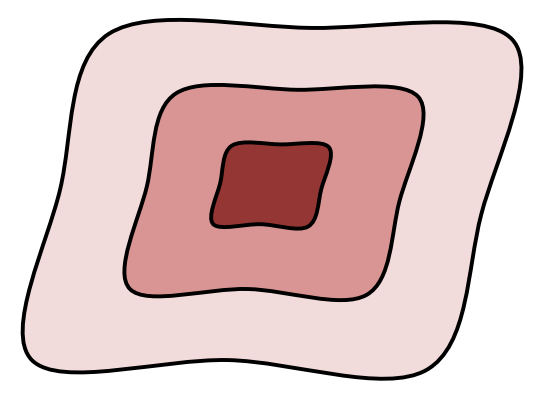

Source: own design.

Since in practice it is possible that a region fulfils more than one definition of our previous classification or demonstrates certain peculiar traits, some specific types of functional regions can be identified further:

- the functional urban region (discussed for instance by Berry 1973; Hall, Hay 1980; Cheshire, Hay 1989),

- the daily urban system (discussed for instance by Berry 1973, Hall 1974; Coombes et al. 1978; in the Czech Republic Kunc et al. 2009),

- the local labour market area (discussed for instance by Smart 1974; Coombes et al. 1979; in the Czech Republic Klapka et al. 2013), and

- the travel-to-work area (discussed for instance by Ball 1980; Coombes, Openshaw 1982). 
Last two instances are very similar if not almost identical.

Functional urban region adds the limitation regarding the quality of a core and consequently the character of spatial flows or interactions organising the region. In this case a core should have an urban character, in other words the flows or interactions should be oriented at a city or a town (fig. 6a). This orientation infers further specifics of functional urban regions. The interactions organising a region possess the character of urban - (suburban) - rural gradient in either direction. Inner structure of functional urban region is very well developed. The urban core provides its suburban and rural hinterland with services, labour opportunities, and the hinterland can serve resident or recreational purposes.

Daily urban system is sometimes misinterpreted as a synonym to a functional urban region. However, it adds further specific to the concept of functional urban region. The flows or interactions organising a daily urban system should be based on daily basis (fig. 6b). It means that they should follow a daily cycle of movements and contacts, a daily dynamics of the organisation of geographical environment. As such the daily urban systems are spatially more limited than functional urban regions, since, unlike the preceding type, only flows and interactions feasible within 24 hours are taken into account. In other respects a daily urban system is similar to a functional urban region.

Local labour market area and travel-to-work area are near synonyms with only a theoretical difference that local labour areas need not necessarily be based on travel-to-work flows (indeed they almost always are). In this sense we consider a labour market area as a very slightly broader term.

Both types of regions differ from the preceding cases in several aspects. They are based on particular spatial flows or interactions that are related to specific movements of persons (i.e. travel-to-work flows) - see figure 6c. The interactions mostly face a restriction to daily cycles of these movements, even if other, weekly, rhythm could be theoretically applied. The interaction need not necessarily be oriented at any core, though mostly they are. In the former aspect local labour markets and travel-towork areas are similar to daily urban systems, in the latter aspect they resemble general functional regions. However, both aspects often intermingle and which one prevails is not a matter of theoretical definition rather than a matter of influence of a particular spatial situation and arrangement. Local labour market areas and travel-to-work areas can be seen as most dynamic concepts of functional regions.

\section{Fig. 6: Specific instance of functional regions}

a) FUR

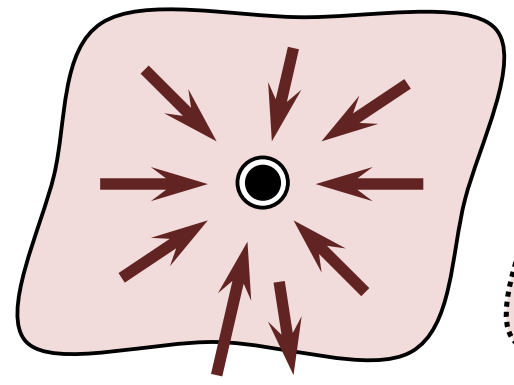

b) DUS

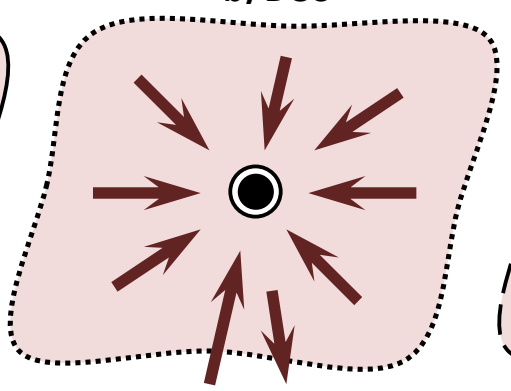

c) LLMA

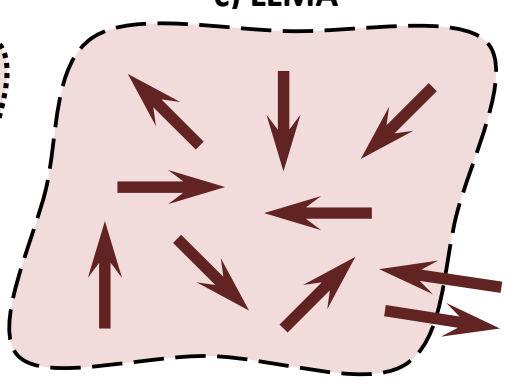

Source: own design

\section{Conclusion}

In our argumentation we have tried to proceed from general to specific instances of functional regions when more those more specific are usually a subset of more general types. In practice the line between the types can be sometimes vague. It should also be noted, hence, that in practice the number of flows or interactions used for definition of functional regions is severely limited unless these are modelled. Usually daily travel-to-work flows are used, since they are relatively easily recognisable in terms of their origin and destination, they are statistically monitored in the population censuses, and they have 
relatively natural character with little planning influence in comparison to other possible flows or interactions.

Of course, we can use travel-to-school flows, though they are affected by the state policy, we can use shopping flows, thought they are almost impossible to be acquired for larger areas. The use of almost unique interaction (daily travel-to-work flows) further blurs the differences between theoretically defined types of functional regions.

We should be also aware of the fact that all types of functional regions can occur at different hierarchical levels, can have different size that partly depends on the hierarchical position of the cores in the settlement system (in case these cores are identified) and on the character of spatial flow or interaction ( $c f$. for instance commuting to elementary schools and commuting to secondary schools).

Finally the issue of regions with a multiple core can be put forward in short. Objectively such functional regions do exist (if they fulfil the theoretical presuppositions that region-organising flows or interactions are oriented at some kind of node) and the question regards particularly the relations between individual cores within one region.

\section{Literature}

[1] ABLER, R., ADAMS, J. S., GOULD, P. Spatial Organization. Prentice-Hall, London, 1972.

[2] BALL, R. M. The use and definition of travel-to-work areas in Great Britain: some problems. Regional Studies 1980, 14 (2), 125-139. DOI: 10.1080/09595238000185121.

[3] BAŠOVSKÝ, O., LAUKO, V. Úvod do regionálnej geografie. SPN, Bratislava, 1990.

[4] BERRY, B. J. L. Growth Centers in the American Urban System: Community development and regional growth in the sixties and seventies. Balinger Publishing Company, Cambridge (Mass.), 1973.

[5] BROWN, L. A., HOLMES, J. The delimitation of functional regions, nodal regions, and hierarchies by functional distance approaches. Journal of Regional Science, 1971, 11 (1), 57-72. DOI: 10.1111/j.1467-9787.1971.tb00240.x.

[6] CHESHIRE, P. C., HAY, D. G. Urban Problems in Western Europe: An Economic Analysis. HarperCollins Academic/Routledge, London, 1989.

[7] CLAVAL, P. Introduction to regional geography. Blackwell, Oxford, 1998.

[8] COOMBES, M., G., DIXON, J. S., GODDARD, J. B., OPENSHAW, S., TAYLOR, P. J. Towards a more rational consideration of census areal units: daily urban systems in Britain. Environment and Planning A, 1978, 10 (10), 1179-1185.

[9] COOMBES, M. G., DIXON, J. S., GODDARD, J. B., OPENSHAW, S., TAYLOR, P. J. Daily urban systems in Britain: from theory to practice. Environment and Planning A 1979, 11 (5), $565-574$.

[10] COOMBES, M. G., OPENSHAW, S. The use and definition of travel-to-work areas in Great Britain: some comments. Regional Studies, 1982, 16 (2), 141-149.

[11] DZIEWOŃSKI, K. Concepts and terms in the field of economic regionalization. In Macka, M. ed.: Economic regionalization. Academia, Praha, 1967. 25-36.

[12] GREGORY, D., JOHNSTON, R., J., PRATT, G., WATTS, M., WHATMORE, S. eds. The Dictionary of Human Geography. $5^{\text {th }}$ edition, Wiley-Blackwell, Oxford, 2009.

[13] HAGGETT, P. Locational Network Analysis in Human Geography. Arnold, London, 1965.

[14] HALÁS, M., KLAPKA, P. Distance decay function and its application in the territory of the Czech Republic. Acta Universitatis Palackianae Olomucensis, Facultas Rerum Naturalium, Geographica, 2012, 43 (1), 57-60.

[15] HALL, P. The containment of urban England. Geographical Journal, 1974, 140 (3), 386-408. DOI: $10.2307 / 1796533$.

[16] HALL, P. G., HAY, D. G. Growth Centres in the European Urban System. Heinemann Educational, London, 1980. 
[17] JOHNSTON, R., J., GREGORY, D., PRATT, G., WATTS, M. eds. The Dictionary of Human Geography. $4^{\text {th }}$ edition, Blackwell, Oxford, 2000.

[18] KLAPKA, P., TONEV, P. Regiony a regionalizace. In Toušek, V., Kunc, J., Vystoupil, J. (eds.). Ekonomická a sociální geografie. Vydavatelství a nakladatelství Aleš Čeněk, Plzeň, 2008. 371397.

[19] KLAPKA, P., HALÁS, M., TONEV, P., BEDNÁŘ M. Functional regions of the Czech Republic: comparison of simple and advanced methods of regional taxonomy. Acta Universitatis Palackianae Olomucensis, Facultas Rerum Naturalium, Geographica, 2013, 44 (1), (in print).

[20] KUNC, J., FRANTÁL, B., KLAPKA, P., MARYÁŠ, J. Denní urbánní systémy a jejich časoprostorová organizace: teoreticko-metodický základ. In Klímová, V. (ed.). XII. mezinárodní kolokvium o regionálních vědách. Brno: Masarykova univerzita, 2009. s. 177-184.

[21] MORRILL, R. L. The Spatial Organization of Society. Duxbury Press, North Scituate, 1974.

[22] Nystuen, J. D., DACEY, M. F. A graph theory interpretation of nodal regions. Regional Science Association, Papers and Proceedings, 1961, 7, 29-42.

[23] PHILBRICK, A. K. Principles of areal functional organization in regional human geography. Economic Geography, 1957, 33 (4), 299-336.

[24] SMART, M. W. Labour market areas: uses and definition. Progress in Planning, 1974, 2 (4), 239-353.

[25] ULLMAN, E. L. Geography as spatial interaction. University of Washington Press, Seattle and London, 1980.

The contribution is a part of the research carried out in the Centre for Analysis of Regional Systems (cenars.upol.cz). 